Kredo 4 (2020)
KREDO: Jurnal Ilmiah Bahasa dan Sastra
Terakreditasi Sinta 4 berdasarkan Keputusan Direktorat
Jenderal Penguatan Riset dan Pengembangan,
Kementerian Riset, Teknologi dan Pendidikan Tinggi
Republik Indonesia
Nomor: 23/E/KPT/2019. 08 Agustus 2019
https://jurnal.umk.ac.id/index.php/kredo/index

\title{
PERBANDINGAN KATA PENGGOLONG NOMINA DALAM BAHASA MANDARIN DAN BAHASA INDONESIA
}

\author{
Selvia ${ }^{1}$, Imelda $^{2}$ \\ selvia21@gmail.com
}

Universitas Kristen Maranatha, Indonesia

Info Artikel

Sejarah Artikel

Diterima

27 April 2020

Disetujui

13 Oktober 2020

Dipublikasikan

28 Oktober 2020

\section{Keywords}

noun classifier, Indonesian language,

Mandarin language

\section{Kata Kunci}

kata penggolong

nomina, Bahasa

Indonesia, Bahasa

Mandarin

\section{Abstract}

Today, the close relationship between Indonesia and the People's Republic of China in various aspects, influences the increasing number of Chinese people who learn Indonesian language and culture, and vice versa. The need for literature on Indonesian and Chinese languages and cultures is increasing too. This situation requires a lot of research related to the two languages. The research conducted by the author this time is a comparison between classifier words in Mandarin and Indonesian. The purpose of this research is to find out the similarities and differences in classsifier words in Chinese and Indonesian and how their use in sentences. This research uses descriptive method with contrastive analysis. Through this study the authors found that both language have a common syntactic equation in common. Research results show that the classifier words unit of measure in both language also has the same provisions. In both languages, one type of stuff (except: people \& animals) can use more than one classifier word. The difference between Indonesian and Mandarin classifier words is found in the types and preconditions of using classifier words for people, stuff, preconditions of classifier word that can be omitted in sentences and preconditions of classifier words that can be reduplicated.

\begin{abstract}
Abstrak
Dewasa ini, hubungan erat antara Indonesia dengan Republik Rakyat Tiongkok dalam berbagai aspek, mempengaruhi peningkatan jumlah orang Tiongkok yang mempelajari bahasa dan budaya Indonesia, maupun sebaliknya. Kebutuhan literatur mengenai bahasa dan budaya Indonesia dan Tiongkok pun semakin bertambah. Situasi ini mengharuskan banyak dilakukan penelitian terkait kedua bahasa tersebut. Penelitian yang dilakukan penulis kali ini adalah komparasi antara kata penggolong dalam bahasa Mandarin dengan kata penggolong dalam bahasa Indonesia. Tujuan dilakukannya penelitian ini adalah peneliti ingin menemukan persamaan dan perbedaan kata penggolong dalam bahasa Mandarin dan bahasa Indonesia serta penggunaannya dalam kalimat. Penelitian ini menggunakan metode deskriptif dengan analisis kontrastif. Penulis membatasi kajian pada kata penggolong nomina dalam bahasa Mandarin dan bahasa Indonesia. Hasil penelitian menunjukkan selain memiliki persamaan konstruksi sintaksis umum, kata penggolong satuan ukur dalam kedua bahasa ini juga memiliki ketentuan yang sama. Dalam kedua bahasa tersebut satu jenis benda (selain orang \&binatang) dapat menggunakan lebih dari satu kata penggolong. Perbedaan kata penggolong bahasa Indonesia dan bahasa Mandarin terdapat pada jenis dan prasyarat penggunaan kata penggolong untuk orang, benda, prasyarat kata penggolong yang bisa dihilangkan dalam kalimat dan prasyarat kata penggolong yang bisa direduplikasi.
\end{abstract}

\section{PENDAHULUAN}

Bahasa Mandarin merupakan salah satu bahasa internasional yang perlu dikuasai pada era sekarang. Fenomena semakin banyaknya pemelajar Indonesia yang ingin menguasai bahasa Mandarin membuat sejumlah instansi non formal seperti tempat kursus dan bimbingan belajar membuka secara khusus kelas pembelajaran Bahasa Mandarin.
Berbagai institusi pendidikan formal pun memasukkan Bahasa Mandarin sebagai salah satu materi pembelajaran. Pembelajaran Bahasa Mandarin di Indonesia mengalami perkembangan yang cukup signifikan.

Seiring dengan eratnya hubungan Indonesia dengan Republik Rakyat Tiongkok dalam berbagai aspek seperti 


Kredo 4 (2020)
KREDO: Jurnal Ilmiah Bahasa dan Sastra
Terakreditasi Sinta 4 berdasarkan Keputusan Direktorat
Jenderal Penguatan Riset dan Pengembangan,
Kementerian Riset, Teknologi dan Pendidikan Tinggi
Republik Indonesia
Nomor: 23/E/KPT/2019. 08 Agustus 2019
https://jurnal.umk.ac.id/index.php/kredo/index

ekonomi, politik, sosial maupun budaya, jumlah orang Tiongkok yang mempelajari bahasa dan budaya Indonesiapun semakin bertambah. Rohmadi, Sugiri, Nugraheni (dalam Pusvita, Winda Dewi, dkk: 2019) Pemerintah Indonesia telah mengizinkan beberapa universitas yang ada di Indonesia untuk membuka kelas khusus bagi pelajar Bahasa Indonesia dari negara asing. Saat ini eksistensi Bahasa Indonesia semakin mencuat dengan banyaknya orang asing yang berminat mempelajari Bahasa Indonesia.

Dalam Bahasa Mandarin, untuk menyatakan jumlah suatu objek atau benda diperlukan kata penggolong. Kata penggolong dalam Bahasa Mandarin untuk setiap objek atau benda berbedabeda, tergantung bentuk, ukuran, jenis, dan lainnya. Kata penggolong Bahasa Mandarin sangat beragam, maka perlu untuk dikuasai dengan baik dan sesuai penggunaan yang tepat. Perlu diketahui dalam pembelajaran Bahasa Mandarin sering pula ditemukan kesalahan penggunaan kata penggolong Bahasa Mandarin khususnya pemelajar dasar yang baru mengenal jenis-jenis dan penggunaannya.

Kondisi di atas memicu sejumlah peneliti untuk melakukan penelitian komparasi terkait kedua bahasa tersebut. Saat proses pembelajaran dimungkinkan terjadinya kesalahan, sebagai contoh adalah penggunaan kata penggolong. Kata penggolong dalam Bahasa Mandarin dengan kata penggolong dalam Bahasa Indonesia memiliki kesamaan dan perbedaan. Berdasar dari kondisi di atas, peneliti ingin membantu para pemelajar Indonesia yang mempelajari Bahasa Mandarin maupun pembelajar Tiongkok yang mempelajari Bahasa Indonesia. Untuk itu peneliti melakukan penelitian mengenai perbandingan kata pengggolong Bahasa Mandarin dengan kata penggolong Bahasa Indonesia. Penelitian kali ini, penulis batasi hanya sebatas kajian pada kata penggolong nomina dalam Bahasa Mandarin dan Bahasa Indonesia. Tujuan dari penelitian ini adalah untuk mengetahui persamaan dan perbedaan kata penggolong nomina dalam Bahasa Mandarin dan Bahasa Indonesia serta penggunaannya dalam kalimat.

Penelitian sebelumnya pernah dilakukan oleh Irwana Nawangsari dengan judul "Analisis Kesalahan Gramatikal Kata Bantu Bilangan 次 cì, 遍 biàn, 趟 tàng Pada Mahasiswa Semester III Sastra Cina Fakultas Ilmu Budaya Universitas Brawijaya. Penelitian ini membahas tentang kesalahan yang dilakukan oleh pemelajar dikarenakan kurangnya pemahaman akan perbedaan penggunaan dari ketiga kata bantu bilangan di atas. Penelitian lainnya juga pernah dilakukan oleh Ajeng Ayu Tria Nirmala dengan judul Analisis Penggunaan Kata Bantu Bilangan Bahasa Mandarin Pada Buku Cerita Rakyat 三字 经 (sānzìjing). Penelitian ini membahas tentang penggunaan kata bantu bilangan yang berfungsi untuk menjelaskan unit ataupun satuan dari objek yang disesuiakan dengan konteks cerita yang dibawakan buku cerita tersebut. Lalu peneliti mengelompokkan kata bantu bilangan tersebut sesuai dengan fungsinya. Berdasarakan analisis-analisis kesalahan dalam penggunaanya maka diperlukan satu kajian menyeluruh 


Kredo 4 (2020)
KREDO: Jurnal Ilmiah Bahasa dan Sastra
Terakreditasi Sinta 4 berdasarkan Keputusan Direktorat
Jenderal Penguatan Riset dan Pengembangan,
Kementerian Riset, Teknologi dan Pendidikan Tinggi
Republik Indonesia
Nomor: 23/E/KPT/2019. 08 Agustus 2019
https://jurnal.umk.ac.id/index.php/kredo/index

mengenai kata bantu bilangan/ kata penggolong dalam Bahasa Mandarin dan Bahasa Indonesia.

Manfaat dari penelitian ini adalah memudahkan pemelajar Indonesia untuk menguasai penggunaan kata penggolong nomina dalam Bahasa Mandarin dan memudahkan pemelajar Tiongkok yang sedang mempelajari kata penggolong nomina dalam Bahasa Indonesia.

\section{KAJIAN TEORI}

Menurut Mokh. Yahya, dkk (2018:51-68) penguasaan kosakata adalah modal utama dalam belajar berbahasa. Jumlah kosakata Bahasa Indonesia yang dikuasai oleh pembelajar sangat memengaruhi kemampuan berbahasanya. Sementara itu, Raden Yusuf Sidiq Budiawan dan Rukayati pada Jurnal Kredo (2018:88-97) berjudul "Kesalahan Bahasa Dalam Praktik Berbicara Pemelajaran Bahasa Indonesia Bagi Penutur Asing di Universitas PGRI Semarang tahun 2018" menyatakan kesalahan berbahasa dapat diklasifikasikan menjadi 5 jenis, salah satunya adalah kesalahan dalam kalimat. Kesalahan dari segi kalimat dibagi lagi menjadi 3 jenis, salah satunya adalah kesalahan pilihan kata. Dapat dilihat, penguasaan kosakata dan ketepatan pilihan kata sangat penting dalam mempelajari suatu bahasa, termasuk dalam hal ini adalah kosakata mengenai kata penggolong dan ketepatan pemakaian kata penggolong dalam suatu kalimat. Menurut Nunan (dalam Witarsih, 2019), ada beberapa hal yang dibutuhkan seorang pemelajar untuk dapat menguasai keterampilan berkomunikasi, seseorang setidaknya harus memahami kosa kata, tata bahasa, aturan berbicara, dan aturan penggunaan yang baik. Keempat hal tersebut harus dikuasai agar dapat mencapai indikator ketercapaian pemelajaran yang diharapkan.

Menurut KBBI, kata penggolong adalah kata untuk menggolongkan nomina, biasanya diikuti oleh numeralia. Dalam Bahasa Indonesia, terdapat beberapa penyebutan yang berbeda untuk kata penggolong benda. Madong Lubis menyebutnya dengan istilah kata penyukat. Lubis mengatakan bahwa kata penyukat adalah kata yang terletak di belakang kata bilangan yang menunjukkan suatu ukuran atau sukatan, termasuk ukuran untuk waktu, harga maupun benda. Sementara Gorys Keraf dalam bukunya Tata Bahasa Indonesia menggunakan istilah kata bantu bilangan. Tardjan Hadidjaja memakai istilah kata penunjuk jenis. Kentojono dkk. (2004:190) selain memakai istilah kata penggolong, juga membedakannya dengan kata pengukur. Hasan Alwi, Kridalaksana dan Kentjono memakai istilah kata penggolong.

Berikut sejumlah kata penggolong dalam Bahasa Indonesia:

bentuk untuk cincin, gelang, atau benda yang dapat dibengkokkan/ dilenturkan

buah untuk buah-buahan atau sesuatu diluar golongan manusia dan binatang.

batang untuk pohon, rokok, benda lain berbentuk panjang.

bidang untuk tanah, sawah, benda yang luas dan datar.

belah untuk mata, telinga, benda yang berpasangan.

bilah untuk pisau, pedang, benda tajam lainnya. 


Kredo 4 (2020)
KREDO: Jurnal Ilmiah Bahasa dan Sastra
Terakreditasi Sinta 4 berdasarkan Keputusan Direktorat
Jenderal Penguatan Riset dan Pengembangan,
Kementerian Riset, Teknologi dan Pendidikan Tinggi
Republik Indonesia
Nomor: 23/E/KPT/2019. 08 Agustus 2019
https://jurnal.umk.ac.id/index.php/kredo/index

butir untuk kelereng, telur, benda bulat dan kecil lainnya.

biji untuk mata, jagung, kelereng, padi.

carik untuk kertas.

ekor untuk binatang.

helai untuk kertas, rambut, kain, benda lain yang tipis dan halus.

kuntum untuk bunga.

keping untuk uang logam.

kerat untuk roti, daging.

laras untuk senapan.

orang untuk manusia.

patah untuk kata.

potong untuk baju, celana, bagian/ potongan suatu barang.

pucuk untuk surat, senapan.

rumpun untuk padi, bambu, tumbuhan lain yang berkelompok.

tangkai untuk bunga, pena, benda bertangkai.

utas untuk benang, tali, benda kecil dan panjang.

Bahasa Indonesia masa kini timbul kecenderungan meniadakan kata penggolong jika konteksnya jelas tampak bahwa hal yang dimaksud adalah tunggal. Contohnya: Dia membaca sebuah buku. Kata penggolong "sebuah" tersebut dapat dilesapkan dan tidak menimbulkan perubahan makna kalimat. Secara garis besar kata penggolong dalam Bahasa Indonesia dibagi menjadi tiga yaitu kata penggolong untuk orang (orang), binatang (ekor) dan sesuatu selain orang dan binatang (buah). Alwi (2003:282).

\section{Kata penggolong dalam Bahasa Mandarin}

Dalam Bahasa Mandarin, kata penggolong (量词 liàngcî) adalah kata yang menggolongkan nomina dan verba, umumnya terletak di belakang numeralia. Liu Yuehua (刘月华) dalam bukunya yang berjudul 《实用现代汉语 语法》Shíyòng Xiàndài Hànyǔ Yǔfă membagi kata penggolong Bahasa Mandarin menjadi dua jenis yakni: kata penggolong nomina dan kata penggolong verba.

\section{Kata penggolong nomina}

A. Kata penggolong nomina khusus

1. Kata penggolong untuk benda satuan ( 个体量词 gè tì liàng cí)

Contoh:

条 tiáo (kata penggolong untuk ikan dan celana)

张 zhāng (kata penggolong

untuk kertas, meja, mulut, wajah dan sebagainya).

2. Kata penggolong untuk benda jamak ( 集体量词 jítǐ liàngcí)

Contoh:

套 tào (kata penggolong untuk 1 set benda)

双 shuāng (kata penggolong untuk benda yang memiliki pasangan seperti sepatu, anting dan sebagainya).

3. Kata penggolong satuan ukur (度量 词 dù liàngcí)

a. Satuan panjang: 寸 cùn (inci), 厘 米 límǐ (sentimeter), 米 mǐ (meter), 公里 gōnglǐ (kilometer), dan sebagainya. 


Kredo 4 (2020)
KREDO: Jurnal Ilmiah Bahasa dan Sastra
Terakreditasi Sinta 4 berdasarkan Keputusan Direktorat
Jenderal Penguatan Riset dan Pengembangan,
Kementerian Riset, Teknologi dan Pendidikan Tinggi
Republik Indonesia
Nomor: 23/E/KPT/2019. 08 Agustus 2019
https://jurnal.umk.ac.id/index.php/kredo/index

b. Satuan kapasitas: 毫升 háoshēng (cc), 升 shēng (liter), dan sebagainya.

c. Satuan berat:厅 jīn (setengah kilo), 公 斤 gōngjīn (kilogram), dan sebagainya.

d. Satuan luas:顷 qǐng (are), 平方寸 píngfāngcùn (inci persegi/ inci kuadrat), 平方尺 píngfāngchǐ (kaki persegi/ kaki kuadrat/12 inci persegi), 公顷 gōngq̌ng (hektar), dan sebagainya.

e. Satuan volum: 立方寸 lìfāngcùn (inci kubik), 立方米 lìfāngmǐ (meter kubik) dan sebagainya.

4. Kata penggolong untuk benda yang tidak jelas jumlahnya (不定量词 bú ding liàng cí)

Contoh: 些 xiē (beberapa), 点 diăn (beberapa).

5. Kata penggolong untuk waktu dan pembatasan wilayah pemerintahan /administratif (准量词 zhǔn liàngcí)

Contoh: 年 nián (tahun), 星 期 xīngq̄î (minggu), 天 tiān (hari), 小 时 xiăoshí (jam), 分 fēn (menit), 秒 miăo (detik), 国 guó (negara), 省 shěng (provinsi), 市 shì (kota), 县 xiàn (kabupaten), dan sebagainya.

6. Kata penggolong gabungan nomina dan verba (复合量词 fùhé liàngcí) Contoh: 人次 rén cì, 班次 bān cì, 架次 jià cì, 秒立方米 miăolì fāngmǐ (meter

kubik per detik).
B. Kata penggolong pinjaman dari kata benda (借用量词 jièyòng liàngcí)

Contoh:

碗 wăn (mangkuk)

杯 bēi (gelas)

壸 hú (teko)

身 shēn (badan)

桌 zhuō (meja)

盆 pén (baskom)

车 chē (mobil)

dan sebagainya.

\section{METODE PENELITIAN}

Metode penelitian yang digunakan dalam penelitian ini adalah metode deskriptif dengan analisis kontrastif. (Kridalaksana 2001:13) Analisis kontrastif merupakan suatu metode analisis yang digunakan guna dapat mendeskripsikan persamaan dan perbedaan dua bahasa.

Peneliti menggunakan teknik pengumpulan data berupa studi literatur dengan mencatat, mengkaji, mengelompokkan kata penggolong nomina Bahasa Mandarin dan kata penggolong nomina Bahasa Indonesia dengan merujuk pada dua buku sumber yakni 《实用现代汉语语法》Shíyòng Xiàndài Hànyǔ Yǔfă karya Liu Yuehua dan Tata Bahasa Baku Bahasa Indonesia karya Alwi, H., Soenjono D., Hans L., Anton M. Moeliono. Proses selanjutnya peneliti menganalisis persamaan dan perbedaan kata penggolong nomina dari kedua bahasa tersebut serta menjabarkan penjelasan mengenai penggunaannya berupa contoh penerapan dalam kalimat. 


Kredo 4 (2020)
KREDO: Jurnal Ilmiah Bahasa dan Sastra
Terakreditasi Sinta 4 berdasarkan Keputusan Direktorat
Jenderal Penguatan Riset dan Pengembangan,
Kementerian Riset, Teknologi dan Pendidikan Tinggi
Republik Indonesia
Nomor: 23/E/KPT/2019. 08 Agustus 2019
https://jurnal.umk.ac.id/index.php/kredo/index

\section{HASIL DAN PEMBAHASAN}

Konstruksi umum penggunaan kata penggolong dalam Bahasa Mandarin adalah sebagai berikut: numeralia + kata penggolong + nomina. Contoh kalimat dengan konstruksi umum: 一个苹果 yíge píngguǒ, 一 yī: numeralia; 个 gè: kata penggolong; 苹果 píngguǒ: nomina. Konstruksi umum dalam Bahasa Mandarin berlaku sama dengan penggunaan kata penggolong dalam Bahasa Indonesia.

Konstruksi lain, dengan menambahkan ajektiva sebelum kata penggolong: numeralia + ajektiva + kata penggolong + nomina. Contoh kalimat dengan konstruksi lain: 一个大苹果 yíge dà píngguǒ, 一 ȳì: numeralia; 个 gè: kata penggolong; 大 dà: besar; 苹果 píngguǒ: nomina. Untuk penggunaan konstruksi lain ini dalam Bahasa Indonesia, ajektiva diletakkan setelah nomina.

Berikut beberapa contoh kata penggolong nomina khusus Bahasa Mandarin dan padanannya dalam Bahasa Indonesia.

Kata penggolong untuk orang

\begin{tabular}{|l|l|l|l|}
\hline Bahasa Mandarin & \multicolumn{2}{|l|}{ Bahasa Indonesia } \\
\hline $\begin{array}{l}\text { Kata peng- } \\
\text { golong }\end{array}$ & Contoh kalimat & $\begin{array}{l}\text { Kata peng- } \\
\text { golong }\end{array}$ & Contoh kalimat \\
\hline 个 gè & $\begin{array}{l}\text { 一个学生 } \\
\text { yí ge xuéshēng }\end{array}$ & Orang & Satu orang siswa \\
\cline { 1 - 2 } 位 wèi & $\begin{array}{l}\text { 一位老师 } \\
\text { yí wèi lăoshī }\end{array}$ & Satu orang guru \\
\hline $\begin{array}{l}\text { Penggunaan kata penggolong untuk orang dalam Bahasa Mandarin } \\
\text { disesuaikan dengan nomina yang digunakan (objek dalam kalimat } \\
\text { ini), 个 gè bersifat netral (formal dan informal), digunakan untuk } \\
\text { orang yang seusia atau usisanya lebih muda dari pembicara, 位 wèi } \\
\text { digunakan dalam bahasa formal untuk menyebutkan seseorang } \\
\text { dengan lebih sopan/ hormat. }\end{array}$ \\
\hline
\end{tabular}

$$
\begin{gathered}
\text { Dalam } \\
\text { bengghasa } \\
\text { untuk informal, kata } \\
\text { orang dapat }
\end{gathered}
$$

dilesapkan tanpa mengubah makna kalimat. Contohnya:一（名）护士在场 受 伤 $\bar{y}$ (míng) hùshì zài chăng shòushāng (Satu (orang) perawat terluka di tempat kejadian). Namun jika nomina (objek dalam kalimat) diberi atribut maka kata penggolong wajib dipakai. Contohnya:

(1. a.) 李教授对他的一学生说: “过 来!”。Lǐ jiàoshòu duì tā de yī xuéshēng shuō: "guòlai!"

(1. b.) 李教授对他的一个韩国学生 说: “过来!”。L Li jiàoshòu duì tā de ȳ̄ ge Hánguó xuéshēng shuō: "guòlai!" *李教授对他的一韩国学生说：“过 来!”。*Lǐ jiàoshòu duì tā de yī Hánguó xuéshēng shuō: "guòlai!"

Pada contoh kalimat nomor (1.a.) “李教 授对他的一学生说: “过来!”. L i jiàoshòu duì tā de ȳi xuéshēng shuō: "guòlai!", kata penggolong 个 ge dalam kalimat di atas dapat dilesapkan. Akan tetapi berbeda dengan contoh kalimat nomor (1.b.) 李教授对他的一个韩国学 生说: “过来!”. Lǐ jiàoshòu duì tā de yī ge Hánguó xuéshēng shuō: "guòlai!"。

Dikarenakan terdapat atribut 韩国 Hánguó maka kata penggolong 个 ge wajib dipakai.

(2. a.) 甘肃一警察私放罪犯获刑, 刘 宏伟。Gānsù yī jǐngchá sīfàng zuìfàn huòxíng, Liú Hóngwěi.

(2. b.) 甘肃一个年轻的警察私放罪犯 获刑, 刘宏伟。Gānsù yī ge niánqīng jǐngchá sīfàng zuìfàn huòxíng, Liú Hóngwěi.

*甘肃一年轻的警察私放罪犯获刑, 刘 宏伟。Gānsù yī niánqīng jǐngchá sīfàng zuìfàn huòxíng, Liú Hóngwěi. 


Kredo 4 (2020)
KREDO: Jurnal Ilmiah Bahasa dan Sastra
Terakreditasi Sinta 4 berdasarkan Keputusan Direktorat
Jenderal Penguatan Riset dan Pengembangan,
Kementerian Riset, Teknologi dan Pendidikan Tinggi
Republik Indonesia
Nomor: 23/E/KPT/2019. 08 Agustus 2019
https://jurnal.umk.ac.id/index.php/kredo/index

Pada kalimat nomor (2.b.) 甘肃一个年 轻的警察私放罪犯获刑, 刘宏伟。 Gānsù yī ge niánqīng jǐngchá sīfàng zuìfàn huòxíng, Liú Hóngwěi. Dalam kalimat ini, terdapat atribut 年 轻 niánqīng, kalimat menjadi salah jika kata penggolong 个 ge tidak dipakai.

(3. a.) 浙二医院的一医生昨天下午被 病患打至耳膜撕裂。Zhé'èr yīyuàn de yī yīshēng zuótiān xiàwǔ bèi bìnghuàn dă zhì ěrmó sīliè 。

(3. b.) 浙二医院的一个女医生昨天下 午被病患打至耳膜撕裂。Zhé'èr yīyuàn de yī ge nǘ yīshēng zuótiān xiàwǔ bèi bìnghuàn dă zhì ěrmó sīliè 。

*浙二医院的一女医生昨天下午被病患 打至耳膜撕裂。Zhé'èr yīyuàn de yī nü yīshēng zuótiān xiàwǔ bèi bìnghuàn dă zhì ěrmó sīliè 。

Hal yang sama berlaku pada kalimat nomor (3.b.) dengan atribut “女 nü̈”. Bila nomina 医生 yīshēng yang memiliki atribut 女 nü tidak disertai pemakaian kata penggolong sebelum atribut, maka kalimatnya menjadi salah.

(4. a.)美国的一教师“一夜”变性由男 变女。Měiguó de yī jiāoshī "yí yè" biànxìng yóu nán biàn nü 。

(4. b.) 美国的一个幼儿园教师“一夜” 变性由男变女。Měiguó de ȳi ge youéryuán jiāoshī "yí yè" biànxìng yóu nán biàn nǘ 。

*美国的一幼儿园教师“一夜”变性由男 变女。Měiguó de ȳi youéryuán jiāoshī "yí yè" biànxìng yóu nán biàn nü 。

(5. a.) 一家长边给女儿擦眼镜边说 道: “听话哦! ”Ȳ̄ jiāzhăng biān gěi nǘ'ér cā yănjìng biān shuō dào: "tīnghuà o!"”
(5. b.) 一个年纪大概 40 来岁的家长边 给女儿擦眼镜边说道: “听话哦! ”Ȳ̄ ge niánjì dàgài 40 lái suì de jiāzhăng biān gěi nǘ'ér câ yănjìng biān shuō dào: "tīnghuà o!"

*一年纪大概 40 来岁的家长边给女儿 擦眼镜边说道: “听话哦! ”Ȳ̄ niánjì dàgài 40 lái suì de jiāzhăng biān gěi nǘér cā yănjìng biān shuō dào: "tīnghuà o!"

(6. a.) 据新民网报道, 8 月 9 日, 上海 地铁 2 号线上一老外乘客在座位上晕 倒了。JùXīnmín wăng bàodào, 8 yuè 9

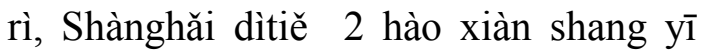
lăowài chéngkè zài zuòwèi shang yūndăo le.

(6. b.) 据新民网报道， 8 月 9 日，上 海地铁 2 号线上一个带着 2 岁小孩的 老外乘客在座位上晕倒了。Jù Xīnmín wăng bàodào, 8 yuè 9 rì, Shànghăi dìtiě 2 hào xiàn shang yī ge dài zhe 2 suì xiăohái de lăowài zài zuòwèi shang yūndǎo le.

*据新民网报道, 8 月 9 日, 上海地铁 2 号线上一带着 2 岁小孩的老外乘客 在座位上晕倒了。Jù Xīnmín wăng bàodào, 8 yuè 9 rì, Shànghăi dìtiě 2 hào xiànshang yî dài zhe 2 suì xiăohái de lăowài zài zuòwèi shang yūndăo le.

Kalimat nomor (4.b.) dengan atribut “幼儿园 youéryuán”, kalimat nomor (5.b.) dengan atribut “年纪大概 40 来岁 niánjì dàgài 40 lái suì”, serta kalimat nomor (6.b.) dengan atribut “带着 2 岁 小孩 dài zhe 2 suì xiăohái”。Tiga kalimat ini menjadi salah jika tidak menggunakan kata penggolong, karena nominanya memiliki atribut. 


Kredo 4 (2020)
KREDO: Jurnal Ilmiah Bahasa dan Sastra
Terakreditasi Sinta 4 berdasarkan Keputusan Direktorat
Jenderal Penguatan Riset dan Pengembangan,
Kementerian Riset, Teknologi dan Pendidikan Tinggi
Republik Indonesia
Nomor: 23/E/KPT/2019. 08 Agustus 2019
https://jurnal.umk.ac.id/index.php/kredo/index

Kata penggolong 个 gè merupakan kata penggolong yang paling umum digunakan dalam Bahasa Mandarin. Selain digunakan untuk orang, 个 gè masih dapat digunakan untuk area (国家 guójiā: negara, 城市 chéngshì: kota, 农 村 nóngcūn: desa, dan lain-lain), unit (宾 馆 bīnguăn: hotel, 饭 店 fàndiàn: restoran, 学校 xuéxiào: sekolah, dan lain-lain), untuk waktu/ masa (季节 jìiié: musim, 月 yuè: bulan, 星期 xīngqī: minggu, 下午 xiàwǔ: sore, 小时 xiǎoshí: jam, dan lain-lain) dan untuk sesuatu lainnya (seperti 苹果 píngguǒ: apel, 玩 具 wánjù: mainan, 花瓶 huāpíng: vas bunga, dan lain-lain).

Contoh penggunaan kata penggolong 个 gè dalam kalimat adalah sebagai berikut:

1. 一个国家不发展经济, 等于自取灭 亡。Yí ge guójiā bù fāzhăn jīngjì, děngyú zìqǔ mièwáng.

2. 对于一个城市来说, 最重要的不是 建筑, 而是规划。Duìyú yí ge chéngshì lái shuō, zuì zhòngyào de bú shì jiànzhù, ér shì guīhuà.

3. 假如你去尊重一个农村的穷人，别 人就会尊重你。Jiărú nǐ qù zūnzhòng yí ge nóngcūn de qióng rén, bié rén jiù huì zūnzhòng nǐ.

4. 你认为泾县是安徽不错的一个县, 对吗? Nǐ rènwéi Jīng xiàn shì Ānhuī bú cuò de yí ge xiàn, duì ma?

5. 他在一个饭店做临时工。Tā zài yí ge fàndiàn zuò línshí gōng.

6. 今晚我们打算在一个宾馆就餐。 Jīnwăn wǒmen dăsuàn zài yí ge bīnguăn jiù cān.

7. 有一次校监去参观一个学校。Yǒu yí cì xiàojiān cānguān yí ge xuéxiào.
8. 没有一个季节比秋天更容易让人忧 伤。Méiyǒu yí ge jìjié bǐ qiūtiān gèng róngyì ràng rén yōushāng.

9. 经过一个月的治疗, 奶奶的病算是 治好了。Jīngguò yí ge yuè de zhìliáo, năinai de bìng suànshì zhì hăo le.

10. 这次的会议一如既往, 还是开了 整整一个下午。Zhè cì huìyì yìrú jìwăng, háishi kāi le zhěngzhěng yí ge xiàwu.

11. 不到一个小时, 球场的门票卖光 了。Bú dào yí ge xiăoshí, qiú chăng de ménpiào mài guāng le.

12. 西方俗浐: “一天一个苹果, 医生 远离你。”。Xīfāng súyán: "yì tiān yí ge píngguǒ, yīshēng yuănlí nǐ."

13. 今天爸爸妈妈给我了一个玩具, 我兴高采烈。Jīntiān bàba māma gěi wǒ le yí ge wánjù, wǒ xìnggāo căiliè.

14. 这是一个花瓶式样的墨西哥漆 器。Zhè shì yí ge huā píng shìyàng de Mòxīgē qīqì.

\section{Kata penggolong untuk binatang}

Kata penggolong untuk binatang dalam bahasa Mandarin digolongkan menjadi 4 jenis yaitu:

只 zhī untuk:

burung(鸟 niăo）

angsa (鹅 é)

katak（青蛙 qīngwā)

panda（大熊猫 dà xióngmāo）

kupu-kupu（蝴蝶 húdié）

harimau（老虎 lăohǔ）

singa（狮子 shīzi）

tikus (老鼠 lăoshǔ)

kelinci（兔子 tùzi）

dan lain-lain. 


Kredo 4 (2020)
KREDO: Jurnal Ilmiah Bahasa dan Sastra
Terakreditasi Sinta 4 berdasarkan Keputusan Direktorat
Jenderal Penguatan Riset dan Pengembangan,
Kementerian Riset, Teknologi dan Pendidikan Tinggi
Republik Indonesia
Nomor: 23/E/KPT/2019. 08 Agustus 2019
https://jurnal.umk.ac.id/index.php/kredo/index

条 tiáo untuk:

ikan（鱼 yú）

anjing（狗 gǒu）

ular（蛇 shé）

naga (龙 lóng)

头 tóu untuk:

kambing (羊 yáng)

keledai (驴 lǘ)

babi（猪 zhū)

gajah (大象 dàxiàng) dan

sapi (牛 niú).

匹 pǐ untuk:

kuda (马 mă)

bagal (马骡 măluó)

unta（骆驼 luòtuo）

Sedangkan kata penggolong untuk binatang dalam Bahasa Indonesia dinyatakan hanya dengan satu kata penggolong yang sama yaitu ekor.

Contohnya:

1. Pagi ini Adi berhasil memancing dua ekor ikan.

2. Tiga ekor serigala tiba-tiba memasuki pemukiman warga.

3. Seekor rubah ditemukan di atas langit-langit rumah warga.

4. Nina membeli empat ekor anjing ras chihuahua.

5. Seekor ular berbisa melukai seorang pemburu di hutan tersebut kemarin siang.

6. Warga Kampung Dukuh Atas menemukan lima ekor kucing terikat di atas pohon mangga.

7. Seekor tupai memanjati pohon kelapa itu.

Kata penggolong 只 zhī selain digunakan untuk binatang dapat pula digunakan untuk menyatakan (se)belah dari sesuatu yang berpasangan, contohnya:

一只手 yì zhī shǒu: satu belah tangan

一只鞋 yì zhī xié: satu belah sepatu

一只眼睛 yì zhī yănjing: satu belah mata

一只耳朵 yì zhī ěrduo: satu belah telinga

Contoh penggunaan kata penggolong 只 zhī dalam kalimat adalah sebagai berikut:

1. 老人的一只手有毛病, 总是籁籁地 抖着。Lăo rén de yì zhī shǒu yǒu máobìng, zǒng shì sùsù de dǒu zhe.

2. 一只帆船在湖面上缓缓飘动着。Yì zhī fánchuán zài húmiàn shang huănhuăn piāodòng zhe.

3. 同样一只鞋, 并不是所有的人穿了 都会合脚。Tóngyàng yì zhī xié, bìng bú shì suǒyǒu de rén chuān le dōu huì héjiăo.

4. 两只眼睛比一只眼睛看得清楚。 Liăng zhī yănjing bǐ yì zhī yănjing kàn de qīngchŭ.

5. 老师像一只手, 带领着我们走出歧 途。Lăoshī xiàng yì zhī shǒu, dàilǐng wǒmen zǒu chū qítú.

6. 随着你的成长, 你会发现你的两只 手中一只手是自助的, 另一只是来 帮助他人的。Suí zhe nǐ de chéngzhăng, nǐ huì fāxiàn nǐ de liăng zhī shǒu zhōng yì zhī shǒu shì zìzhù de, lìng yì zhī shì bāngzhù tā rén de.

7. 结婚前睁大眼睛。结婚后要闭一只 眼睛。Jiéhūn qián zhēngdà yănjing. Jiéhūn hòu yào bì yì zhī yănjing.

8. 如果你关闭一只眼睛, 你无法获得 深度知觉。Rúguǒ nǐ guānbì yì zhī yănjing, nǐ wúfă huò dé shēndù zhījué.

9. 我失去了一只臂膀, 就睁开了一只 


Kredo 4 (2020)
KREDO: Jurnal Ilmiah Bahasa dan Sastra
Terakreditasi Sinta 4 berdasarkan Keputusan Direktorat
Jenderal Penguatan Riset dan Pengembangan,
Kementerian Riset, Teknologi dan Pendidikan Tinggi
Republik Indonesia
Nomor: 23/E/KPT/2019. 08 Agustus 2019
https://jurnal.umk.ac.id/index.php/kredo/index

眼睛。Wǒ shīqù le yì zhī jiānbăng, jiù zhēng kāi le yì zhī yănjing.

10. 给我一只耳朵, 我便给你声音。

Gěi wǒ yì zhī ěrduo, wǒ biàn gěi nǐ shēngyīn.

11. 麦克鲁汉: “从来没有一只耳朵能 被嘴巴真正的说服！”。 Màikè Lǔhàn: "Cónglái méiyou yì zhī ěrduo néng bèi zǔiba zhēnzhèng de shuōfú".

Kata penggolong 条 tiáo selain digunakan untuk binatang juga dapat digunakan untuk menyatakan yang lain, seperti:

一条路 yì tiáo lù: sebuah jalan.

一条船 yì tiáo chuán: sebuah perahu.

一条毛巾 yì tiáo máojīn: sebuah handuk.

一条河 yì tiáo hé: sebuah sungai

一条航线 yì tiáo hángxiàn: satu jalur penerbangan

Contoh penggunaan kata penggolong 条 tiáodalam kalimat adalah sebagai berikut:

1. 做任何事之前, 先给自己一条路, 时刻提醒自己, 坚持下去。Zuò rènhé shì zhī qián, xiān gěi zìjĭ yì tiáo lù, shíkè tíxǐng zìjǐ, jiānchí xiàqu.

2. 我和小伙伴陆续跳上一条船, 准备 去航海。Wǒ hé xiăo huǒbàn lùxù tiào shang yì tiáo chuán, zhǔnbèi qù hánghăi.

3. 他把一条毛巾放在我双腿下面。Tā bă yì tiáo máojīn fàng zài wǒ shuāng tǔi xià miàn.

4. 人生就像一条河, 河里的水流到哪 里都还是水。Rénshēng jiù xiàng yì tiáo hé, hé li de shǔi liú dào nă li dōu háishi shǔi.

210 | Jurnal Kredo Vol. 4 No. 1 Oktober 2020
5. 一条航线需要多少飞机? Yì tiáo hángxiàn xūyào duōshao fēijī?

6. 一条铁路, 把边疆和内地紧紧联 系在一起。Yì tiáo tiělù, bă biānjiāng hé nèidì jǐnjǐn liánxì zài yìqǔ.

7. 他一条腿不吃劲, 走路一㾉一拐 的。Tā yì tiáo tuǐ bù chījìn, zǒulù yì qué yì guăi de.

8. 真扫兴, 钓了半天也没钓上一条 鱼。Zhēn săoxìng, diào le bàn tiān yě méi diào shang yì tiáo yú.

9. 一条公路修进山里, 给荒凉的山 村带来了生气。Yì tiáo gōnglù xiūjìn shānli, gěi huāngliáng de shāncūn dài lai le shēngqì.

10. 南京长江大桥仿佛一条钢铁巨 龙, 横跨在江面上。Nánjīng chángjiāng dà qiáo fãngfú yì tiáo gāngtiě jùlóng, héngkuà zài jiāng mian shang.

11. 最近, 首都机场又开辟了一条国 际航线。Zuìjìn, shǒudū jī chăng yòu kāi pì le yì tiáo guójì hángxiàn.

12. 一条小溪淙淙作响, 从山脚下流 过。Yì tiáo xiăoxī cóngcóng zuò xiăng, cóng shānjiăo xià liúguo.

13. 如果舍弃一粒粒的小石子, 就没 有一条条的大马路。Rúguǒ shěqì yí lìlì de xiăo shízi, jiù méiyou yì tiáo tiáo de dà mă lù.

14. 村子附近有一条小河, 孩子们常 去那里捉泥鳅。Cūnzi fùjìn yǒu yì tiáo xiăo hé, háizimen cháng qù nà li zhuō níqiū.

15. 这是一条僻静的小巷, 很少有车 辆来往。Zhè shì yì tiáo pìjìng de xiăoxiăng, hěn shăo yǒu chē liàng lái wăng.

16. 不知从哪儿窝出一条蛇, 吓得她 


Kredo 4 (2020)
KREDO: Jurnal Ilmiah Bahasa dan Sastra
Terakreditasi Sinta 4 berdasarkan Keputusan Direktorat
Jenderal Penguatan Riset dan Pengembangan,
Kementerian Riset, Teknologi dan Pendidikan Tinggi
Republik Indonesia
Nomor: 23/E/KPT/2019. 08 Agustus 2019
https://jurnal.umk.ac.id/index.php/kredo/index

失声大叫。Bù zhī cóng năr cuànchū yì tiáo lóng, xiā de tā shī shēng dà jiào.

Kata penggolong nomina khusus dalam bahasa Mandarin dapat direduplikasi, seperti 条条 tiáotiáo, 张张 zhāngzhāng, 件件 jiànjiàn, dan lain-lain, reduplikasi tersebut memiliki makna 'tiap, banyak, atau satu per satu', contoh:

1. 条条大路通罗马tiáotiáo dà lù tōng Luómă.

2. 一张张可爱的笑脸 yì zhāng zhāng kě'ài de xiàoliăn.

3. 一件件好看的新衣裳 yí jiàn jiàn háokàn de xīn yīshăng.

4. 就像一把把巨大的伞 Jiù xiàng yì bă bă jùdà de săn.

5. 一辆辆马车停在外面 Yí liàng liàng măchē tíng zài wài mian

Sedangkan kata penggolong nomina pinjaman dalam Bahasa Mandarin tidak dapat direduplikasi, contoh:

*公斤公斤 gōngjīn gōngjīn

*毫升毫升 háoshèng háoshèng

*国国 guóguó

*省省 shěngshěng

*县县 xiànxiàn

Pada contoh di atas terlihat bahwa syarat kata penggolong Bahasa Mandarin yang tidak dapat direduplikasi adalah kata penggolong nomina satuan ukur dan kata penggolong pembatasan wilayah administratif.

Sementara dalam Bahasa Indonesia, reduplikasi kata penggolong nomina memiliki makna 'banyak'. Kata penggolong nomina Bahasa Indonesia dapat direduplikasi dengan ketentuan sebagai berikut:

a. Wajib menambahkan prefix ber- di depan kata penggolong.

b. Hanya berlaku untuk kata penggolong berjumlah satu atau dua suku kata yang termasuk di dalam kategori: kata penggolong nomina pinjaman (selain kata penggolong nomina pinjaman 'orang' dan 'buah'); kata penggolong benda jamak; kata penggolong satuan ukur, kata penggolong untuk pengukuran waktu (selain kata penggolong 'detik' dan 'menit').

Contoh kata penggolong nomina Bahasa Indonesia yang dapat direduplikasi adalah sebagai berikut:

1. Berkilo-kilo beras selundupan telah diamankan oleh pihak berwajib kemarin siang di Majalengka.

2. Berliter-liter minyak dibagikan kepada kaum papa di bulan Ramadhan.

3. Berpiring-piring nasi terbuang percuma.

4. Bergelas-gelas air sirup telah tertata rapi di atas meja.

5. Pak lurah membagikan berkarungkarung terigu kepada warga kelurahan Dukuh Utara.

6. Telah ditemukan bermeter-meter kabel bekas di gorong-gorong Jalan W.R. Supratman Jakarta pada Sabtu petang tadi.

Contoh kata penggolong nomina bahasa Indonesia yang tidak dapat direduplikasi adalah sebagai berikut:

*Berorang-orang datang ke sana.

*berbuah-buah

*bernegara-negara

*berprovinsi-provinsi 


Kredo 4 (2020)
KREDO: Jurnal Ilmiah Bahasa dan Sastra
Terakreditasi Sinta 4 berdasarkan Keputusan Direktorat
Jenderal Penguatan Riset dan Pengembangan,
Kementerian Riset, Teknologi dan Pendidikan Tinggi
Republik Indonesia
Nomor: 23/E/KPT/2019. 08 Agustus 2019
https://jurnal.umk.ac.id/index.php/kredo/index

*berkabupaten-kabupaten

*berdetik-detik pun telah berlalu

*bermenit-menit

Kalimat yang diberi tanda bintang merupakan kalimat yang salah, seperti yang telah diterangkan di atas, bahwa syarat kata penggolong Bahasa Mandarin yang tidak dapat direduplikasi adalah kata penggolong nomina satuan ukur dan kata penggolong pembatasan wilayah administratif. Sementara dalam Bahasa Indonesia, kalimat yang diberi tanda bintang dinyatakan salah karena bentuk reduplikasi tidak berlaku pada kata penggolong 'orang', 'buah' dan kata penggolong untuk pengukuran waktu 'detik', 'menit'. Hal ini dikarenakan reduplikasi 'detik' dan 'menit' tidak memiliki makna 'proses waktu yang lama'. Jika kita cermati, sama halnya dengan Bahasa Mandarin bentuk reduplikasi dalam Bahasa Indonesia pun tidak berlaku pada kata penggolong nomina pinjaman pembatasan wilayah pemerintahan dan administratif, contohnya kata 'kecamatan', 'kelurahan', 'kabupaten', 'provinsi', 'negara'. Ini dikarenakan kata 'kecamatan', 'kelurahan', 'kabupaten', 'provinsi', 'negara' dan sebagainya berjumlah lebih dari dua suku kata.

Baik dalam bahasa Mandarin maupun bahasa Indonesia, kata penggolong satuan ukur (berat,kapasitas, dsb) serta kata penggolong nomina pinjaman yang menjadi alat untuk mengukur, kata penggolong nomina jumlah jamak tidak dapat dihilangkan pemakaiannya karena dapat membuat jumlah nomina menjadi tidak jelas atau mengubah makna. Contohnya adalah sebagai berikut:

\section{2 | Jurnal Kredo} Vol. 4 No. 1 Oktober 2020
1. 一毫升石油多少钱? Yì háoshèng shíyóu duōshao qián?

*一石油多少钱? Yì shíyóu duōshao qián?

2. 重 100 公斤的一个胖子 Zhòng 100 gōngjīn de yí ge pàngzi.

*重 100 的一个胖子 Zhòng 100 de yí ge pàngzi

3. 两斤大米 liăng jīn dàmǐ *两大米 liăng dàmı̌

4. 一勺食盐 yì sháo shíyán * 一食盐 yī shíyán

5. 一群人 yì qún rén *一人 yì rén

6. dua liter air *dua air

7. Lima ratus gram tepung terigu

* Lima ratus tepung terigu

8. Empat kilogram beras

* Empat beras

9. Satu kelompok orang

* Satu orang

10. Satu sendok makan garam dapur

* Satu garam dapur

11. Dia telah berjalan sejauh tujuh ratus kilometer.

*Dia telah berjalan sejauh tujuh ratus.

12. Lima meter kain linen .

* Lima kain linen.

Kalimat yang diberi tanda bintang adalah kalimat yang salah karena dengan menghilangkan kata penggolong satuan berat '斤 jīn', satuan kapasitas 'liter', kata penggolong nomina pinjaman yang menjadi alat untuk mengukur, kata penggolong nomina jumlah jamak '群, 'kelompok', 'bungkus' maka jumlah nomina yang dimaksud menjadi tidak jelas atau membuat makna kalimat menjadi berubah. 


Kredo 4 (2020)
KREDO: Jurnal Ilmiah Bahasa dan Sastra
Terakreditasi Sinta 4 berdasarkan Keputusan Direktorat
Jenderal Penguatan Riset dan Pengembangan,
Kementerian Riset, Teknologi dan Pendidikan Tinggi
Republik Indonesia
Nomor: 23/E/KPT/2019. 08 Agustus 2019
https://jurnal.umk.ac.id/index.php/kredo/index

\section{SIMPULAN}

Dari hasil analisis data dan pembahasan mengenai kata penggolong dalam Bahasa Indonesia dan Bahasa Mandarin dapat disimpulkan persamaan dan perbedaan kata penggolong dari kedua bahasa tersebut. Kedua bahasa tersebut memiliki konstruksi sintaksis umum yang sama yaitu numeralia + kata pengggolong + nomina. Untuk kata penggolong satuan ukur, kedua bahasa memiliki ketentuan yang sama karena kata penggolong satuan ukur berlaku umum. Dalam kedua bahasa tersebut satu jenis benda (selain orang dan binatang) dapat menggunakan lebih dari satu kata penggolong, contoh dalam Bahasa Indonesia untuk senapan, kata penggolong yang dapat dipilih adalah "laras" atau "pucuk"; untuk kertas, kata penggolong yang dapat dipilih adalah "carik", "lembar" atau "helai". Begitu pula dengan beberapa benda dalam Bahasa Mandarin, contohnya 地图dìtú: peta, dapat menggunakan kata penggolong “张zhāng” atau ”幅fú”.

Perbedaan kata penggolong Bahasa Indonesia dan Bahasa Mandarin adalah kata penggolong dalam Bahasa Mandarin jauh lebih kaya dan cenderung lebih detil dibandingkan dengan kata penggolong dalam Bahasa Indonesia. Sebagai contoh kata penggolong untuk binatang. Kata penggolong untuk binatang dalam Bahasa Mandarin terdiri dari empat jenis（只 zhī 、条 tiáo、头 tóu 、匹 pǐ), sedangkan dalam Bahasa Indonesia dapat digunakan kata penggolong "ekor" untuk semua jenis binatang. Dalam Bahasa Mandarin setiap binatang memiliki kata penggolong masing-masing, beberapa binatang yang bisa dikatakan memiliki ciri-ciri hampir serupa ternyata memiliki penggunaan kata penggolong yang berbeda. Dalam Bahasa Mandarin kata penggolong untuk orang dapat dibedakan menjadi tiga jenis. Dalam bahasa formal sebagai bentuk rasa hormat dapat digunakan 位wèi、名 míng, dalam situasi netral (informal maupun formal) dapat digunakan kata penggolong 个 gè, sementara dalam Bahasa Indonesia hanya memiliki satu jenis kata penggolong untuk orang dan tidak dibedakan penggunaannya dalam situasi formal maupun informal. Bahasa Indonesia juga memiliki beberapa kata penggolong yang penggunaannya sudah ditetapkan/ disesuaikan untuk bendabenda lainnya (selain orang dan binatang), namun lambat laun kata penggolong tersebut mengalami penyamarataan, digantikan dengan kata penggolong "buah". Kata penggolong "buah" ini dapat digunakan untuk menyatakan benda lain secara umum, sedangkan dalam Bahasa Mandarin wajib menggunakan kata penggolong sesuai kaidah. Jika terjadi kekeliruan saat memilih kata penggolong yang tepat dalam maka kalimat tersebut menjadi salah.

Dalam bahasa informal, kata penggolong nomina satuan ukur dalam Bahasa Indonesia (yang berjumlah satu atau dua suku kata) umumnya dapat ditambahkan akhiran -an, tetapi tidak berlaku untuk kata penggolong 'orang' dan 'buah'. Contohnya: "Buah ini dijual kiloan". "Handuk dijual lusinan". Akhiran -an dalam kalimat tersebut bermakna "per-kilo" dan "per lusin". Kata penggolong nomina pinjaman 


Kredo 4 (2020)
KREDO: Jurnal Ilmiah Bahasa dan Sastra
Terakreditasi Sinta 4 berdasarkan Keputusan Direktorat
Jenderal Penguatan Riset dan Pengembangan,
Kementerian Riset, Teknologi dan Pendidikan Tinggi
Republik Indonesia
Nomor: 23/E/KPT/2019. 08 Agustus 2019
https://jurnal.umk.ac.id/index.php/kredo/index

dalam Bahasa Indonesia dapat dihilangkan dan tidak mengubah makna kalimat, sementara dalam Bahasa Mandarin kata penggolong wajib hadir dalam kalimat karena dengan menghilangkan kata penggolong maka makna kalimat menjadi tidak jelas, kecuali kata penggolong untuk orang seperti 个 gè, 名 míng, 位 wèi jika nomina (objek dalam kalimat) tidak diberi atribut.

Kata penggolong Bahasa Mandarin yang tidak dapat direduplikasi adalah kata penggolong nomina satuan ukur dan kata penggolong pembatasan wilayah administratif. Sementara dalam Bahasa Indonesia bentuk reduplikasi tidak berlaku pada kata penggolong 'orang', 'buah' dan kata penggolong untuk pengukuran waktu 'detik', 'menit'.

\section{DAFTAR PUSTAKA}

Alwi, H., Soenjono, D., Hans, L., Anton, M.Moeliono. 1988. Tata Bahasa Baku Bahasa Indonesia. Balai Pustaka.

Budiawan, Raden Y.S, Rukayati. 2018. Kesalahan Bahasa Dalam Praktik Berbicara Pemelajaran Bahasa Indonesia Bagi Penutur Asing di Universitas PGRI Semarang. Jurnal Kredo. Vol 2, No 1. 88-97.

Gorys, Keraf.1994. Tata Bahasa Indonesia. Flores: Nusa Indah.

Hadidjaja, Tardjan. 1956. Tata Bahasa Indonesia. Yogyakarta: Indonesia N.V.

He, J. 2008. 现代汉语言两次研究增编. Beijing: Normal University Press.

Kentjono, Joko., Frans, Asisi Datang., dkk. 2004. Tata Bahasa Acuan Bahasa Indonesia untuk Penutur Asing. Jakarta: Wedatama Widya Sastra.

Kridalaksana, Harimurti. 2009. Kamus Linguistik. Jakarta: Gramedia Pustaka Utama.

Liu, Y.H. 2001. 实用现代汉语语法. Shangwu Press.

Her, One-Soon and Hsieh, Chen-Tien, 2010. On the Semantic Distinction between Classifiers and Measure Words in Chinese. Language and Linguistics 11.3:527551.

Pusvita, Winda Dewi., Andayani, Winarni, Retno. 2019. Kesalahan Pengucapan Kosakata Pelajar BIPA di UPT Bahasa Universitas Sebelas Maret Surakarta, Jurnal Kredo. Vol 2, No 2, 206-225.

214 | Jurnal Kredo Vol. 4 No. 1 Oktober 2020 


Kredo 4 (2020)
KREDO: Jurnal Ilmiah Bahasa dan Sastra
Terakreditasi Sinta 4 berdasarkan Keputusan Direktorat
Jenderal Penguatan Riset dan Pengembangan,
Kementerian Riset, Teknologi dan Pendidikan Tinggi
Republik Indonesia
Nomor: 23/E/KPT/2019. 08 Agustus 2019
https://jurnal.umk.ac.id/index.php/kredo/index

Shao, J.M. 2007. 现代汉语. Shanghai Jiaoyu Press.

Witarsih, Woro. 2019. Analisis Kesulitan Pelafalan Konsonan Bahasa Indonesia (Studi Kasus terhadap Pemelajar BIPA Asal Tiongkok di Universitas Atma Jaya Yogyakarta), Jurnal Kredo. Vol 2, No 2. 242-255.

Yahya, Mokh., Andayani, Kundharu Saddhono. 2018. Hubungan Penguasaan Kosakata Dengan Kesalahan Diksi Dalam Kalimat Bahasa Indonesia Mahasiswa BIPA Level Akademik. Jurnal Kredo. Vol 1, No 2. 51-68.

Zhang, Z.G. 1982. 现代汉语.Renmin Jiaoyu Press. 